\title{
Low rates of all-cause revision in displaced subcapital femoral neck fractures treated with hip hemiarthroplasty - a retrospective review of 4516 patients from a single institute
}

Chi-Yung Yeung ${ }^{1,2}$, Shang-Wen Tsai ${ }^{1,2}$, Po-Kuei Wu ${ }^{1,2}$, Cheng-Fong Chen ${ }^{1,2^{*}} \mathbb{D}$, Ming-Chau Chang ${ }^{1,2}$ and Wei-Ming Chen ${ }^{1,2}$

\begin{abstract}
Background: Femoral neck fracture (FNF) is among the commonest fractures affecting the geriatric population. Hemiarthroplasty (HA) is a standard treatment procedure and has been performed by hip surgeons for decades. Recently, primary total hip replacement has proved advantageous for the treatment of such fractures.

The aim of this study is to retrospectively review all causes of failure of all patients who underwent HA in our institute and reevaluated whether HA remains a favourable choice of treatment for patients with displaced FNFs.

Methods: A total of 4516 patients underwent HA at our centre from 1998 to 2017. The HA implants included unipolar and bipolar prostheses. Patients diagnosed with displaced FNF, underwent primary HA initially, required second revision procedures, and followed up for a minimum of 36 months were included in this study. Data were collected and comprehensively analysed.

Results: In 4516 cases, 99 patients underwent second surgeries. The revision rate was 2.19\%. Reasons for failure were acetabular wear $(n=30,30.3 \%)$, femoral stem subsidence $(n=24,24.2 \%)$, periprosthetic fracture $(n=22$, $22.2 \%)$, infection ( $n=16,16.2 \%)$, and recurrent dislocation $(n=7,7.1 \%)$. The mean follow-up period was 78.1 months. The interval between failed HA and revision surgery was 22.8 months.
\end{abstract}

Conclusion: HA has a low revision rate and remains a favourable choice of treatment for patients with displaced FNFS.

Levels of evidence: Level III, Retrospective Cohort Study, Therapeutic Study.

Keywords: Femoral neck fractures, Austin Moore hemiarthroplasty, Bipolar hemiarthroplasty, Hemiarthroplasty failure, Conversion total hip replacement

\footnotetext{
* Correspondence: cf chen@vghtpe.gov.tw

'Department of Orthopaedics and Traumatology, Taipei Veterans General Hospital, No. 201, Sec 2, Shi-Pai Road, Taipei 112, Taiwan, Republic of China ${ }^{2}$ Department of Orthopaedics, School of Medicine, National Yang-Ming University, No. 201, Sec. 2, Shipai Rd., Beitou District, Taipei City 11217,

Taiwan, Republic of China
}

C The Author(s). 2020 Open Access This article is licensed under a Creative Commons Attribution 4.0 International License, which permits use, sharing, adaptation, distribution and reproduction in any medium or format, as long as you give appropriate credit to the original author(s) and the source, provide a link to the Creative Commons licence, and indicate if changes were made. The images or other third party material in this article are included in the article's Creative Commons licence, unless indicated otherwise in a credit line to the material. If material is not included in the article's Creative Commons licence and your intended use is not permitted by statutory regulation or exceeds the permitted use, you will need to obtain permission directly from the copyright holder. To view a copy of this licence, visit http://creativecommons.org/licenses/by/4.0/ The Creative Commons Public Domain Dedication waiver (http://creativecommons.org/publicdomain/zero/1.0/) applies to the data made available in this article, unless otherwise stated in a credit line to the data. 


\section{Background}

Femoral neck fracture (FNF) is among the commonest fractures affecting the geriatric population. In displaced fracture types, treatments include closed or open reduction and internal fixation, hemiarthroplasty (HA), and total hip replacement (THR). HA is a frequently recommended treatment and has been performed for decades [1]. Nevertheless, the use of primary THR has increased substantially in clinical research. Several randomised control trials have also demonstrated that for displaced FNF, THR results in superior functional outcomes to those of HA. However, THR is more expensive and results in higher complication rates. The clinical results appear contradictory [2-6]. The aim of this study is to retrospectively review all causes of failure of all patients who underwent HA in our institute. Whether HA remains a favourable choice of treatment for patients with displaced FNF can thereby be evaluated.

\section{Methods}

This was a retrospective cohort study and was performed at a single trauma centre. From 1998 to 2017, 4516 patients underwent hemiarthroplasty in our institute following a diagnosis of displaced FNF. The HA implants included the Austin Moore (unipolar monoblock) prosthesis and various bipolar systems (including the Zimmer, Osteonics, and United systems) (Fig. 1).
Patients diagnosed with displaced FNF, underwent primary HA and second revision surgery, and followed up for at least 36 months were included in this study. Patients with multiple fractures, open fractures, pathological fractures, or paediatric fractures; patients who had received previous ipsilateral hip surgeries; and patients whose follow-up periods were insufficiently long were excluded. Data were collected in our database system and comprehensively analysed. The study was approved for publication by the institutional review board of our hospital.

Surgical procedures were performed by various surgeons according to the protocol of our department. Prophylactic antibiotics, including first-generation cephalosporin, were administered $30 \mathrm{~min}$ before skin incision and macrolides to patients with a penicillin allergy. Under spinal or general anaesthesia, patients were operated on in a lateral position, using either the anterolateral (Watson-Jones) approach or the posterior (Moore or Southern) approach. The prosthesis system was chosen according to the preference of the surgeon, and the use of cement fixation depended on bone quality and was decided intraoperatively. A portable radiograph of the hip joint was examined before the patient was transferred back to the ward unit. Oral analgesic agent and intravenous morphine (PRN) were administered for pain control if not contraindicated. Intravenous

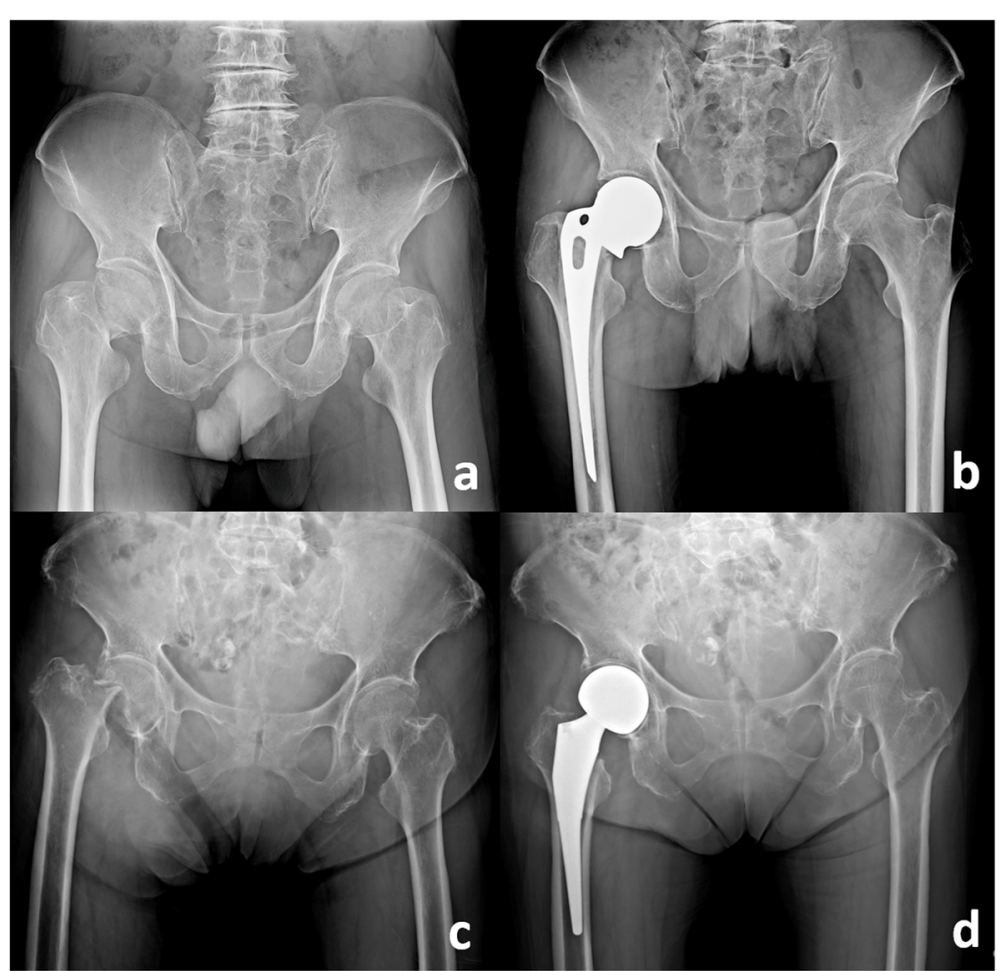

Fig. 1 Displaced Femoral Neck Fractures and Hemiarthroplasties. a Patient diagnosed with right displaced femoral neck fracture; b Cemented Austin-Moore hemiarthroplasty; c Patient diagnosed with right displaced femoral neck fracture; d Cementless bipolar hemiarthroplasty 
Table 1 Patient demographics and clinical conditions. (Total $N=99$ )

\begin{tabular}{|c|c|}
\hline \multicolumn{2}{|l|}{ Age (year) } \\
\hline Mean + SD & $76.4 \pm 8.7$ \\
\hline Range & $44-93$ \\
\hline \multicolumn{2}{|l|}{ Gender } \\
\hline Male & $57(57.6)$ \\
\hline Female & $42(42.4)$ \\
\hline \multicolumn{2}{|l|}{ BMI Index (kg/m2) } \\
\hline Mean + SD & $22.8 \pm 3.7$ \\
\hline Range & $16.9-30.9$ \\
\hline \multicolumn{2}{|l|}{ ASA Classification } \\
\hline Class 2 & $32(32.3)$ \\
\hline Class 3 & $41(41.4)$ \\
\hline Class 4 & $26(26.3)$ \\
\hline \multicolumn{2}{|l|}{ Fracture Side } \\
\hline Left & $54(54.5)$ \\
\hline Right & $45(45.5)$ \\
\hline \multicolumn{2}{|c|}{ Interval between ER Consultation to Surgery (days) } \\
\hline Mean + SD & $1.8 \pm 1.6$ \\
\hline Range & $1-8$ \\
\hline \multicolumn{2}{|c|}{ Duration of Follow-up (months) } \\
\hline Mean + SD & $78.1 \pm 55.8$ \\
\hline Range & $40-219$ \\
\hline \multicolumn{2}{|l|}{ Length of Hospital Stay (days) } \\
\hline Mean + SD & $8.2 \pm 7.0$ \\
\hline Range & $3-49$ \\
\hline \multicolumn{2}{|c|}{ Patients Expired during Follow-up Period } \\
\hline Number of Patients Expired & $14(14.1)$ \\
\hline \multicolumn{2}{|c|}{ Duration between Primary HA to Expiration (months) } \\
\hline Mean + SD & $81.9 \pm 43.0$ \\
\hline Range & $27-183$ \\
\hline \multicolumn{2}{|l|}{ Reasons of Expiration } \\
\hline Infection $^{a}$ & $4(28.6)$ \\
\hline Malignancy & $9(64.3)$ \\
\hline Cardiovascular disease & $1(7.1)$ \\
\hline
\end{tabular}

Data presented as $\mathrm{N}(\%)$ unless otherwise stated in the table

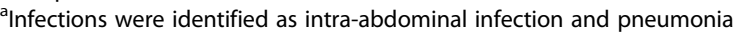

antibiotics were continuously administered every $8 \mathrm{~h}$ after surgery for 1 day and prolonged depending on the patient's clinical condition.

Each patient had his or her own chart with detailed records, including personal data, the mechanism of injury and associated conditions, fracture type and classification, course of management, implantation details, fixation technique, surgical approach, and functional recovery process. Regular follow-ups were arranged after discharge for all patients. The anteroposterior and lateral radiograph views of the wound condition were evaluated during each outpatient department visit.

Statistical analysis was performed using SPSS version 24.0 statistical software (IBM-SPSS, Inc., Chicago, IL, USA). An independent $t$ test, chi-square test, and multinomial logistic regression analysis were used. $P<.05$ was used to indicate statistical significance $\left({ }^{*} P<.05\right.$, ${ }^{* *} P<.01$, *** $P<.001)$. 


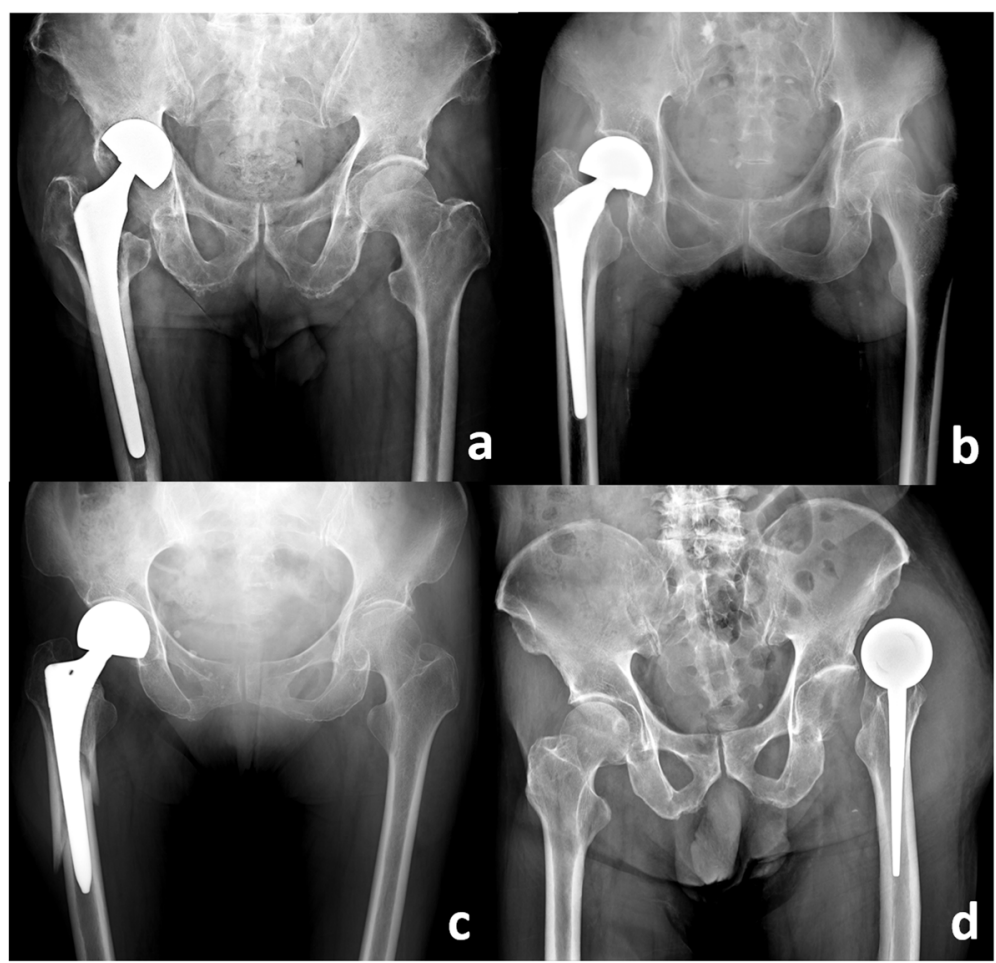

Fig. 2 Reasons of failed hemiarthroplasty. a Acetabulum wearing with central migration; b Femoral stem subsidence; c Periprosthetic fracture; d Recurrent dislocation

\section{Results}

Of 4516 patients, 99 were found to receive second revision surgery, including 5 open reductions and internal fixations, 18 revision hemiarthroplasties, and 76 conversion THRs. The revision rate of failed HA and the conversion rate of THR were $2.19 \%$ (99 of 4516 ) and $1.68 \%$ (76 of 4516), respectively. The average age of the patients at the time of the injury was $76.4 \pm 8.7$ years (range: 44-93 years). Of the patients, 57 were male and 42 were female. The physical health and associated medical conditions of the patients were rated based on the American Society of Anaesthesiologists' (ASA) physical status classification: 32 patients were in class II, 41 patients were in class III, and 26 patients were in class IV. The mean body weight index (BMI) was $22.8 \mathrm{~kg} / \mathrm{m}^{2}$ (range: 16.9-30.9). Of the fractures, 54 were left sided and 45 were right sided. The interval between injury and surgery was $1.8 \pm 1.6$ days (range: $1-8$ ). The mean follow-up period was $78.1 \pm 55.8$ months (range: 40 219). Fourteen patients expired during the follow-up period due to infections (intra-abdominal infection and pneumonia were identified), malignancies, or cardiovascular diseases. All patients' demographic data are summarised in Table 1.

The revision cases involved 24 and 75 patients who had undergone unipolar and bipolar HA, respectively. Of the HA procedures, 72 were cementless and 27 were cemented; 64 patients were operated on with the anterolateral (Watson-Jones) approach and 35 underwent the posterior (Moore or Southern) approach. The mean femoral cup size was $47.3 \pm 3.6 \mathrm{~mm}$ (range: $40-54$ ). Reasons for failure included acetabular wear $(n=30,30.3 \%)$, femoral stem subsidence $(n=24,24.2 \%)$, periprosthetic fracture $(n=22,22.2 \%)$, infection $(n=16,16.2 \%)$, and recurrent dislocation $(n=7,7.1 \%)$ (Fig. 2). The interval between primary HA and revision surgery was $22.8 \pm 30.0$ months. Data are summarised in Tables 2, 3 and 4.

\section{Discussion}

The National Health Insurance Research Database of Taiwan documents more than 100,000 hip fracture diagnoses that have caused more than 2000 in-hospital mortalities every year. Along with the trend of rapid population aging, standard management for hip fractures is a prominent theme and represents a challenge for orthopaedic surgeons $[7,8]$.

For displaced FNFs, HA is the standard treatment. However, one study reported that the rate of THR use as a primary treatment option significantly increased from 0.7 to $7.7 \%$ between 1999 and 2011. Younger patients are being treated with THRs due to their superior mobility and range of joint motion [9, 10]. Clinical research has also shown that THR is superior to HA. For example, Ravi reported that THR is associated with 
Table 2 Surgical details, reasons of failed hemiarthroplasty and types of revision surgery

\begin{tabular}{|c|c|}
\hline \multicolumn{2}{|l|}{ Implant of Hemiarthroplasty } \\
\hline Unipolar (Austin-Moore) Hemiarthroplasty & $24(24.2)$ \\
\hline Bipolar Hemiarthroplasty & $75(75.8)$ \\
\hline \multicolumn{2}{|l|}{ Fixation Technique } \\
\hline Cementless & $72(72.7)$ \\
\hline Cemented & $27(27.3)$ \\
\hline \multicolumn{2}{|l|}{ Surgical Approach } \\
\hline Anterolateral (Watson-Jones) Approach & $64(64.6)$ \\
\hline Posterior (Moore/ Southern) Approach & $35(35.4)$ \\
\hline \multicolumn{2}{|l|}{ Femoral Cup Size (mm) } \\
\hline Mean + SD & $47.3 \pm 3.6$ \\
\hline Range & $40-54$ \\
\hline \multicolumn{2}{|l|}{ Reasons of Failed Hemiarthroplasty } \\
\hline Acetabulum Wearing & $30(30.3)$ \\
\hline Femoral Stem Subsidence & $24(24.2)$ \\
\hline Periprosthetic Fracture & $22(22.2)$ \\
\hline Infection & $16(16.2)$ \\
\hline Recurrent Dislocation & $7(7.1)$ \\
\hline \multicolumn{2}{|c|}{ Interval between Primary HA to Second Surgery (months) ${ }^{a}$} \\
\hline Mean + SD & $22.8 \pm 30.0$ \\
\hline Range & $1-176$ \\
\hline
\end{tabular}

Data presented as $\mathrm{N}(\%)$ unless otherwise stated in the table

anterval between Primary Surgery (Unipolar / Bipolar Hemiarthroplasty) to Second Surgery (Open Reduction and Internal Fixation / Revision Hemiarthroplasty / Conversion Total Hip Replacement

lower revision surgery rates and significantly reduces the total costs of hospitalisation. Nevertheless, Sonaje et al. stated that HA yielded superior functional outcomes and cost-effectiveness to THR. Wang et al. also reported lower proportional hazard values for reoperation in patients treated with HA compared with those treated with a THR [2-6]. Although clinical results are controversial, the surgical procedure of HA has a much shorter duration, results in less tissue damage and exposure, reduces blood loss, improves primary stability, and reduces dislocation and complication rates compared with THR. Moreover, catastrophic metallosis and osteolysis are rarely observed in hemiarthroplasty. These advantages of HA ostensibly make it a superior treatment for older adults with various underlying comorbidities [1, 5].

Some concerns in relation to HA have been discussed in other studies: The reoperation rate for failed HA is reportedly as high as $24 \%$, and the problem of acetabular wear has been noted as the primary cause of HA failure [11-15]. These concerns might provide additional motivation for the recommendation of primary THR for FNF displacement. However, in the present study, the HA failure rate and the THR conversion rate were 2.19 and $1.68 \%$, respectively. In this study, the reasons for the failure of HA were acetabular wear (30.3\%), femoral stem subsidence (24.2\%), periprosthetic fracture (22.2\%), infection (16.2\%), and recurrent dislocation (7.1\%). The prevalence of acetabular wear, femoral stem subsidence, and periprosthetic fracture were similar within the first 6 months after primary HA according to a multinomial logistic regression analysis. The main cause of early failure was periprosthetic fracture, but the cause of failure became evenly distributed for all 5 groups as time elapsed, and the rates of acetabular wear gradually increased in patients followed up for more than 3 years. A significant difference was demonstrated using a statistical analysis $\left(P<.001^{* * * *)}\right)$. The aggressive prevention of postoperative trauma is ostensibly more critical than is long-term acetabular wear.

No significant difference was noted in the comparison among the groups for the $5 \mathrm{HA}$ failure types in terms of age, sex, BMI index, ASA classification, prosthesis use, fixation technique, surgical approach, and femoral cup size. The risk factor of HA failure was not identified. Peter et al. found that higher ASA scores and BMI indexes $(>40)$ are strong predictors of revision THR requirement, but similar results were not obtained in our data analysis. Further studies are required to determine the major predictors of $\mathrm{HA}$ failure [16]. 
Table 3 Comparison between different reasons of failed hemiarthroplasties

\begin{tabular}{|c|c|c|c|c|c|c|}
\hline \multirow[t]{2}{*}{ Total $N=99$} & $\begin{array}{l}\text { Acetabulum } \\
\text { wearing }\end{array}$ & $\begin{array}{l}\text { Femoral stem } \\
\text { subsidence }\end{array}$ & $\begin{array}{l}\text { Recurrent } \\
\text { dislocation }\end{array}$ & $\begin{array}{l}\text { Periprosthetic } \\
\text { fracture }\end{array}$ & Infection & $p$-value \\
\hline & $n=30$ & $n=24$ & $n=7$ & $n=22$ & $n=16$ & \\
\hline \multicolumn{7}{|l|}{ Age (year) } \\
\hline$<80$ & $19(63.3)$ & $11(45.8)$ & $4(57.1)$ & $11(50.0)$ & $11(68.8)$ & 0.564 \\
\hline$\geq 80$ & $11(36.7)$ & $13(54.2)$ & $3(42.9)$ & $11(50.0)$ & $5(31.3)$ & \\
\hline \multicolumn{7}{|l|}{ Gender } \\
\hline Male & $17(56.7)$ & $14(58.3)$ & $2(28.6)$ & $13(59.1)$ & $11(68.8)$ & 0.552 \\
\hline Female & $13(43.3)$ & $10(41.7)$ & $5(71.4)$ & $9(40.9)$ & $5(31.3)$ & \\
\hline \multicolumn{7}{|l|}{ BMI $\left(\mathrm{kg} / \mathrm{m}^{2}\right)$} \\
\hline$\leq 18.5$ & $4(15.4)$ & $3(14.3)$ & $0(0)$ & $2(13.3)$ & $4(26.7)$ & 0.298 \\
\hline$>18.5-25$ & $13(50.0)$ & $10(47.6)$ & $4(80.0)$ & $13(86.7)$ & $7(46.7)$ & \\
\hline$>25-30$ & $7(26.9)$ & $7(33.3)$ & $1(20.0)$ & $0(0)$ & $4(26.7)$ & \\
\hline$>30-40$ & $2(7.7)$ & $1(4.8)$ & $0(0)$ & $0(0)$ & $0(0)$ & \\
\hline \multicolumn{7}{|l|}{ ASA Classification } \\
\hline Type 2 & $12(40.0)$ & $8(33.3)$ & $3(42.9)$ & $4(18.2)$ & $5(31.3)$ & 0.425 \\
\hline Type 3 & $14(46.7)$ & $8(33.3)$ & $2(28.6)$ & $9(40.9)$ & $8(50.0)$ & \\
\hline Type 4 & $4(13.3)$ & $8(33.3)$ & $2(28.6)$ & $9(40.9)$ & $3(18.8)$ & \\
\hline \multicolumn{7}{|c|}{ Implant of Hemiarthroplasty } \\
\hline Unipolar HA & $8(26.7)$ & $5(27.8)$ & $2(33.3)$ & $0(0)$ & $3(21.4)$ & 0.987 \\
\hline Bipolar HA & $22(73.3)$ & $13(72.2)$ & $4(66.7)$ & $8(100)$ & $11(78.6)$ & \\
\hline \multicolumn{7}{|l|}{ Fixation Technique } \\
\hline Cementless & $21(70.0)$ & $18(75.0)$ & $4(57.1)$ & $17(77.2)$ & $12(75.0)$ & 0.859 \\
\hline Cemented & $9(30.0)$ & $6(25.0)$ & $3(42.9)$ & $5(22.7)$ & $4(25.0)$ & \\
\hline \multicolumn{7}{|l|}{ Surgical Approach } \\
\hline $\begin{array}{l}\text { Anterolateral (Watson- } \\
\text { Jones) }\end{array}$ & $20(66.7)$ & $11(45.8)$ & $6(85.7)$ & $12(59.1)$ & $14(87.5)$ & 0.060 \\
\hline $\begin{array}{l}\text { Posterior (Moore/ } \\
\text { Southern) }\end{array}$ & $10(33.3)$ & $13(54.2)$ & $1(14.3)$ & $9(40.9)$ & $2(12.5)$ & \\
\hline \multicolumn{7}{|l|}{ Femoral Cup Size (mm) } \\
\hline$\leq 45$ & $8(26.7)$ & $9(37.5)$ & $4(57.1)$ & $7(35.0)$ & $4(25.0)$ & 0.315 \\
\hline $45-50$ & $15(50.0)$ & $8(33.3)$ & $1(14.3)$ & $4(20.0)$ & $4(25.0)$ & \\
\hline$\geq 50$ & $7(23.3)$ & $7(29.2)$ & $2(28.6)$ & $9(45.0)$ & $8(50.0)$ & \\
\hline \multicolumn{7}{|c|}{ Primary to Second Surgery (year) } \\
\hline$\leq 0.5$ & $4(13.3)$ & $7(29.2)$ & $5(71.4)$ & 14 (63.6) & $4(25.0)$ & $0.001^{* * *}$ \\
\hline$>0.5-1$ & $1(3.3)$ & $7(29.2)$ & $0(0.0)$ & $1(4.5)$ & $4(25.0)$ & \\
\hline$>1-2$ & $8(26.7)$ & $5(20.8)$ & $1(14.3)$ & $1(4.5)$ & $4(25.0)$ & \\
\hline$\geq 3$ & $17(56.7)$ & $5(20.8)$ & $1(14.3)$ & $6(27.3)$ & $4(25.0)$ & \\
\hline
\end{tabular}

Data presented as $\mathrm{N}(\%)$ unless otherwise stated in the table

${ }^{*} p$-value $<0.05$, ${ }^{* *} p$-value $<0.01$, ${ }^{* * *} p$-value $<0.001$

The risk of periprosthetic fractures when using cemented or cementless stems are currently discussed. Olof GS et al. stated cementless femoral stems are not recommended for the treatment of FNFs in geriatrics high number of due to late-occurring periprosthetic fractures [17]. However, James $\mathrm{K}$ et al. reported periprosthetic fractures occur equally in cemented and cementless stems under the Vancouver classification [18]. The use of cemented or cementless stems for FNFs remains another controversial issue. From the multinomial logistic regression analysis of this study, the odds ratio of risk of periprosthetic fracture is 2.155 in the cementless group comparing to the cemented group (after adjustment of age and gender), but no significance difference $(P=$ 
Table 4 Comparison between unipolar (Austin Moore) hemiarthroplasty and bipolar hemiarthroplasty

\begin{tabular}{|c|c|c|c|}
\hline Total $N=99$ & $\begin{array}{l}\text { Unipolar } \\
n=24\end{array}$ & $\begin{array}{l}\text { Bipolar } \\
n=75\end{array}$ & $p$-value \\
\hline \multicolumn{4}{|l|}{ Age (year) } \\
\hline$<80$ & $0(0)$ & $56(74.7)$ & \multirow[t]{2}{*}{$0.001^{* * *}$} \\
\hline$\geq 80$ & 24(36.7) & 19(25.3) & \\
\hline \multicolumn{4}{|l|}{ Gender } \\
\hline Male & 20(83.3) & $37(49.3)$ & \multirow[t]{2}{*}{$0.003^{* *}$} \\
\hline Female & $4(16.7)$ & $38(50.7)$ & \\
\hline \multicolumn{4}{|l|}{ BMI $\left(\mathrm{kg} / \mathrm{m}^{2}\right)$} \\
\hline$\leq 18.5$ & $5(25.0)$ & $8(12.9)$ & \multirow[t]{4}{*}{0.51} \\
\hline$>18.5-25$ & $11(55.0)$ & $36(58.1)$ & \\
\hline$>25-30$ & $3(15.0)$ & 16(25.8) & \\
\hline$>30-40$ & $1(5.0)$ & $2(3.2)$ & \\
\hline \multicolumn{4}{|l|}{ ASA Classification } \\
\hline Type 2 & $8(33.3)$ & $24(32.0)$ & \multirow[t]{3}{*}{0.985} \\
\hline Type 3 & $10(41.7)$ & $31(41.3)$ & \\
\hline Type 4 & $6(25)$ & $20(26.7)$ & \\
\hline \multicolumn{4}{|l|}{ Surgical Approach } \\
\hline Anterolateral (Watson-Jones) & $16(66.7)$ & $48(64.0)$ & \multirow[t]{2}{*}{0.812} \\
\hline Posterior (Moore/ Southern) & $8(33.3)$ & $27(36.0)$ & \\
\hline \multicolumn{4}{|l|}{ Cup Size (mm) } \\
\hline$\leq 45$ & $3(13.0)$ & 29(39.2) & \multirow[t]{3}{*}{0.066} \\
\hline $45-50$ & $10(43.5)$ & $22(29.7)$ & \\
\hline$\geq 50$ & $10(43.5)$ & 23(31.1) & \\
\hline \multicolumn{4}{|c|}{ Primary to Second Surgery (year) } \\
\hline $0.5 y$ & $5(20.8)$ & 29(38.7) & \multirow[t]{4}{*}{0.08} \\
\hline $1 y$ & $1(4.2)$ & $12(16.0)$ & \\
\hline $2 y$ & $7(29.2)$ & $12(16.0)$ & \\
\hline$\geq 3 y$ & $11(45.8)$ & $22(29.3)$ & \\
\hline \multicolumn{4}{|c|}{ Reasons of Failed Hemiarthroplasty } \\
\hline Acetabulum Wearing & $8(33.3)$ & $22(29.3)$ & \multirow[t]{5}{*}{0.986} \\
\hline Femoral Stem Subsidence & $5(20.8)$ & 19(25.3) & \\
\hline Recurrent Dislocation & $2(8.3)$ & $5(6.7)$ & \\
\hline Periprosthetic Fracture & $5(20.8)$ & $17(22.7)$ & \\
\hline Infection & $4(16.7)$ & $12(16.0)$ & \\
\hline
\end{tabular}

Data presented as $\mathrm{N}(\%)$ unless otherwise stated in the table ${ }^{*} p$-value $<0.05,{ }^{* *} p$-value $<0.01,{ }^{* * *} p$-value $<0.001$

$0.282, \mathrm{CI}=0.532-8.736)$ is noted. The result of analysis is presented in Table 5. Further studies are needed for to evaluate the fixation technique of femoral stem in this geriatric population.

This study has limitations. First, it was a single-centre retrospective cohort study. Second, surgeries were performed by different surgeons and using different surgical approaches, fixation methods, and prosthesis systems.
Table 5 Multivariable logistic regression analysis - cemented and cementless fixation for femoral stem in hip hemiarthroplasty

\begin{tabular}{|c|c|c|c|}
\hline & $B$ value & $p$-value & $\begin{array}{l}\text { Multivariable-adjusted } \\
\text { OR }(95 \% \mathrm{Cl})^{\mathrm{a}}\end{array}$ \\
\hline Age & 0.054 & 0.173 & $1.055(0.977-1.140)$ \\
\hline Gender (Female ref.) & 0.102 & 0.865 & $1.107(0.342-3.579)$ \\
\hline $\begin{array}{l}\text { Periprosthetic Fracture } \\
\text { (Acetabulum Wearing ref.) }\end{array}$ & 0.768 & 0.282 & $\mathbf{2 . 1 5 5}(0.532-8.736)$ \\
\hline
\end{tabular}

More comprehensive research and randomised control studies are required to elucidate these results.

\section{Conclusion}

On the basis of the encouraging mid- to long-term outcomes in this population, we consider that hemiarthroplasty remains a favourable choice of treatment for patients with displaced FNFs.

\section{Abbreviations}

FNF: Femoral neck fracture; HA: Hemiarthroplasty; THR: Total hip replacement; ORIF: Open reduction and internal fixation; CRIF: Closed reduction and internal fixation; BMI: Body Mass Index; ASA: American Society of Anaesthesiologists

\section{Acknowledgements}

We thank Yen-Lin Hou of National Defense Medical Center of Taiwan Graduate Institute of Public Health Section of Public Health Administration for providing comprehensive statistical analysis.

\section{Authors' contributions}

All authors (Y.C., T.S., W.P., C.C., C.M. and C.W.) contributed in this research. Y.C. and C.C. were the major contributors in writing this manuscript and data interpretation, and were the First Author and Corresponding Author respectively. All authors read and approved the final manuscript.

\section{Funding}

This research did not receive any specific grant from funding agencies in the public, commercial, or not-for-profit sectors.

\section{Availability of data and materials}

The datasets analysed during the current study are not publicly available due to the health policy of protection of patient privacy announced by the Ministry of Health and Welfare of Taiwan but are available from the corresponding author on reasonable request.

\section{Ethics approval and consent to participate}

This article consisted of a retrospective cohort study which contained information of patients and has been approved by The Institutional Review Board of Taipei Veterans General Hospital of Taiwan with TPEVGH IRB No. 2020-03-011CC. Informed consents were written and obtained from all individual participants included in the study.

\section{Consent for publication}

Not Applicable.

\section{Competing interests}

The authors declare that they have no conflict of interest in this study. Individual and Combined \& Blinded conflict of interest statements are attached. 
Received: 19 July 2020 Accepted: 15 October 2020

Published online: 22 October 2020

\section{References}

1. Sheth NP, Dattilo JR, Schwarzkopf R. Evaluation and management of failed hemiarthroplasty. J Am Acad Orthop Surg. 2018;26(20):717-26.

2. Dimitriou D, Helmy N, Hasler J, Flury A, Finsterwald M, Antoniadis A. The role of total hip arthroplasty through the direct anterior approach in femoral neck fracture and factors affecting the outcome. J Arthroplast. 2019; 34(1):82-7.

3. Wang Z, Bhattacharyya T. Outcomes of hemiarthroplasty and total hip arthroplasty for femoral neck fracture: a medicare cohort study. J Orthop Trauma. 2017;31(5):260-3.

4. Florschutz AV, Langford JR, Haidukewych GJ, Koval KJ. Femoral neck fractures: current management. J Orthop Trauma. 2015;29(3):121-9.

5. Ravi B, Pincus D, Khan H, Wasserstein D, Jenkinson R, Kreder HJ. Comparing complications and costs of total hip arthroplasty and hemiarthroplasty for femoral neck fractures: a propensity score-matched, population-based study. J Bone Joint Surg Am. 2019;101(7):572-9.

6. Ullmark G. Femoral head fractures: hemiarthroplasty or total hip arthroplasty? Hip Int. 2014;24(Suppl 10):e12-4.

7. Chie WC, Yang RS, Liu JP, Tsai KS. High incidence rate of hip fracture in Taiwan: estimated from a nationwide health insurance database. Osteoporos Int. 2004;15(12):998-1002.

8. Wu TY, Hu HY, Lin SY, Chie WC, Yang RS, Liaw CK. Trends in hip fracture rates in Taiwan: a nationwide study from 1996 to 2010. Osteoporos Int. 2017;28(2):653-65.

9. Miller BJ, Callaghan JJ, Cram P, et al. Changing trends in the treatment of femoral neck fractures: a review of the American board of orthopaedic surgery database. J Bone Joint Surg Am. 2014;96:e149.

10. Fisher MA, Matthei JD, Obirieze A, Ortega G, Tran DD, Carnegie DA, et al. Open reduction internal fixation versus hemiarthroplasty versus total hip arthroplasty in the elderly: a review of the national surgical quality improvement program database. J Surg Res. 2013;181:193-8.

11. Chaplin VK, Matharu GS, Knebel RW. Complications following hemiarthroplasty for displaced intracapsular femoral neck fractures in the absence of routine follow-up. Ann R Coll Surg Engl. 2013;95(4):271-4

12. Warwick D, Hubble M, Sarris I, Strange J. Revision of failed hemiarthroplasty for fractures at the hip. Int Orthop. 1998;22(3):165-8.

13. Phillips TW. Thompson hemiarthroplasty and acetabular erosion. J Bone Joint Surg Am. 1989;71(6):913-7.

14. Sipilä J, Hyvönen P, Partanen J, Ristiniemi J, Jalovaara P. Early revision after hemiarthroplasty and osteosynthesis of cervical hip fracture: short-term function mortality unchanged in 102 patients. Acta Orthop Scand. 2004;75: 402-7.

15. Taheriazam A, Saeidinia A. Conversion of failed hemiarthroplasty to total hip arthroplasty: a short-term follow-up study. Medicine (Baltimore). 2017;96(40): e8235.

16. Peters RM, van Steenbergen LN, Stewart RE, Stevens M, Rijk PC, Bulstra SK, Zijlstra WP. Patient characteristics influence revision rate of total hip arthroplasty: american society of anesthesiologists score and body mass index were the strongest predictors for short-term revision after primary total hip arthroplasty. J Arthroplasty. 2020;35(1):188-192.e2.

17. Olof GS, Helene S, Paula KP, Henrik B, Thomas E, André S, et al. Good stability but high periprosthetic bone mineral loss and late-occurring periprosthetic fractures with use of uncemented tapered femoral stems in patients with a femoral neck fracture. Acta Orthop. 2014;85(4):396-402.

18. James K, Paul C, Shivang D, Michael H. Periprosthetic proximal femoral fractures in cemented and uncemented stems according to Vancouver classification: observation of a new fracture pattern. J Orthop Surg Res. 2020;15:100

\section{Publisher's Note}

Springer Nature remains neutral with regard to jurisdictional claims in published maps and institutional affiliations.

Ready to submit your research? Choose BMC and benefit from:

- fast, convenient online submission

- thorough peer review by experienced researchers in your field

- rapid publication on acceptance

- support for research data, including large and complex data types

- gold Open Access which fosters wider collaboration and increased citations

- maximum visibility for your research: over $100 \mathrm{M}$ website views per year

At $\mathrm{BMC}$, research is always in progress.

Learn more biomedcentral.com/submissions 